\title{
DETERMINANTS OF FDI LOCATION CHOICE IN CHINA: A CASE OF TAIWANESE FIRMS
}

\author{
Pham Thi Ngoc Dung ${ }^{a^{*}}$ \\ ${ }^{a}$ School of Finance, University of Economics Hochiminh City, Hochiminh City, Vietnam \\ *Corresponding author: Email: ngocdung1293@gmail.com \\ Article history \\ Received: November $22^{\text {nd }}, 2017$ \\ Received in revised form: December 11 ${ }^{\text {th }}, 2017 \mid$ Accepted: December $13^{\text {th }}, 2017$
}

\begin{abstract}
The agglomeration of FDI in some specific locations in the host country, especially in emerging economies, might lead to the huge disparity in economic development between areas. Therefore, attracting FDI into less-developed areas outside the FDI agglomeration areas is an important mission for sustainable development. This research analyses the impact of location determinants such as market size, living standard, market growth, labor cost and labor availability on firms' decision to locate FDI outside the FDI agglomeration areas. Moreover, the moderating impact of FDI experience on the relationship between location factors and location decisions will be considered based on the data of Taiwanese FDI in China during the period of 1999-2010.
\end{abstract}

Keywords: Agglomeration; China; FDI; Investment determinants; Location choice.

Article identifier: http://tckh.dlu.edu.vn/index.php/tckhdhdl/article/view/371

Article type: (peer-reviewed) Full-length research article

Copyright $(92018$ The author(s).

Licensing: This article is licensed under a CC BY-NC-ND 4.0 


\title{
CÁC NHÂN TỐ ẢNH HƯỞNG ĐẾn QUYÊTT ĐỊNH LỰA CHỘN VI! TRÍ ĐẦU TU' TẠI TRUNG QUỐC: TRƯỜNG HỢP CỦA CÁC DOANH NGHIỆP ĐÀI LOAN
}

\author{
Phạm Thị Ngọc Dung ${ }^{\mathrm{a}^{*}}$ \\ ${ }^{a}$ Khoa Tài chính, Truờng Đại học Kinh tế TP. Hồ Chí Minh, TP. Hồ Chí Minh, Việt Nam \\ "Tác giả liên hệ: Email: ngocdung1293@gmail.com \\ Lịch sử bài báo \\ Nhận ngày 22 tháng 11 năm 2017 \\ Chỉnh sửa ngày 11 tháng 12 năm 2017 | Chấp nhận đăng ngày 13 tháng 12 năm 2017
}

\section{Tóm tắt}

Thực trạng về tích tu vốn FDI tại một số khu vưc nhất định tại nước nhận đầu tu, đặc biệt là các quốc gia đang phát triển, có thể gây nên sự mất cân bằng về phát triển kinh tế giữa các vùng miền. Do đó, nhiệm vu thu hút FDI vào các địa phuơng kém phát triển hơn nằm ngoài vùng tích tu vốn FDI là nhu cầu thiết yếu hiện nay nhằm huớng đến muc tiêu phát triển bền vũng. Nghiên cứu này phân tích tác động của quy mô thị trường, mức sống, tốc độ tăng truơong của thị truờng, chi phí lao động và múc độ sẵn có của nguồn lao động lên quyết định đầu tu tai các tỉnh nằm ngoài vùng tích tu FDI. Ngoài ra, tác động gián tiếp của kinh nghiệm đầu tu lên mối quan hệ giữa các nhân tố thu hút vốn và quyết định vị trí đầu tu cung sẽ được xem xét dụa trên số liệu về đầu tu FDI của Đài Loan tại Trung Quốc trong giai đoạn 19992010.

Từ khoá: FDI; Lựa chọn vị trí; Nhân tố thu hút đầu tư; Tích tụ; Trung Quốc.

Mã số định danh bài báo: http://tckh.dlu.edu.vn/index.php/tckhdhdl/article/view/371

Loại bài báo: Bài báo nghiên cứu gốc có bình duyệt

Bản quyền @ 2018 (Các) Tác giả.

Cấp phép: Bài báo này được cấp phép theo CC BY-NC-ND 4.0 


\section{INTRODUCTION}

Previous studies have argued that multinationals prefer to locate in close proximity to each other, thus lead to an agglomeration of FDI in some specific locations in the host country, particularly in emerging economies which are characterized by uncertainty and less-developed local institution (Filatotchev, Strange, Piesse, \& Lien, 2007). The reason for the cluster of a foreign firm can be explained in several ways. Firstly, multinationals which have similar motives for investing abroad might be attracted by specific locations that have resource endowment or comparative advantage that allow them to achieve their objectives. Secondly, Kang and Jiang (2012) argue that foreign firms can mitigate risks associated with the institutional uncertainty of a particular region and the transaction risk related to dealing with unfamiliar local counterparts and reduce their higher information and search cost by locating near other firms. Thirdly, foreign firms can also enjoy benefits of agglomeration economies such as knowledge spillover, the high availability of specialized production or backward and forward linkages when entering agglomeration areas (Cheng, Chiao, Shih, Lee, \& Cho, 2011).

Although most of the multinationals in emerging countries prefer an agglomeration strategy, some foreign enterprises attempt to explore the untapped market in order to achieve first mover advantages and hope for a higher return by investing outside existing FDI agglomeration. Organizational researchers give several reasons to explain why firms invest outside the agglomeration areas of FDI. Baum and Mezias (1992) argue that firm proximity leads to more intensified competition among firms that are similar in resources and market positioning, thus foreign firms have to pay higher prices for inputs or pace the risk of reducing profit due to intensive competitions and those can be avoided by located outside the agglomeration areas. This is in line with the argument of Chan, Henderson, and Tsui (2008), that the high concentration of firms can lead to several negative externalities and make that location lose their comparative advantage. Especially, strong firms with resource and know-how competitive advantage when pursuing exploitation strategy tend to avoid locating next to weak firms who can take benefits through knowledge spill over and share suppliers and distributors with them (Li \& Park, 2006). Therefore, risks associated with investment in less-explored or riskier locations might not deter all foreign investments as $\mathrm{Wu}$ (2000) argue that the cumulative FDI has a negative relationship with the new FDI because foreign investors might prefer a location with less competitive pressure.

Literature about FDI agglomeration at regional level mainly focuses on FDI in agglomeration areas and explores the reason leading to agglomeration or the effect of agglomeration on later FDI. There is a dearth of studies examining location characteristics that would encourage firm to venture outside the agglomeration areas. This research contributes to the literature about FDI location choice by analysing the effect of location factors on firm's decision to enter unpopular locations of FDI, in other words, identifying the "centrifugal forces" (Lien \& Filatotchev, 2015, p. 637) that encourage MNEs to venture outside the agglomeration areas, thus fills the gap in FDI literature. Moreover, previous researchers about determinants of FDI location choice mainly examine the effect of location factors and firm characteristics on FDI location choice separately, thus receive 
inconsistent results. This research is based on the assumption that both location factors and firm characteristics have an impact on location decision process. Our sample will be divided into two sub-samples including experienced investors and non-experienced investors and then consider the effect of location factors on FDI location decision for each group.

China was chosen as a host country in this research because of China, one of the world's largest emerging economy, is a large geographical area, which makes the benefits, costs, and risks of venturing FDI in China very differently from province to province. Thus, inward FDI in China can provide better opportunity to explore FDI location determinants at the regional level. We focused on the Taiwanese FDI in China because of several reasons. Firstly, the size of Taiwanese market is limited, which encourages Taiwanese firms to venture abroad to find a market and achieve better economies of scale. Secondly, Taiwan is one of the most important investors in China (Table 1), so the secondary data about Taiwanese FDI in China is available and easier to access. Thirdly, Taiwan is geographically located next to China, which allows Taiwanese investors to have better knowledge about the advantages and risks of each province in China, so the location decision of Taiwanese firms might better reflect the locational characteristics at the regional level in China compared to other firms located far away. Fourthly, Lien and Filatotchev (2015) argue that culture difference might affect the location choice of foreign investors. Therefore, the effect of culture on location decision in China can be mitigated by choosing Taiwan as a home nation because Taiwan is considered to have a similar cultural heritage with China.

\begin{tabular}{ll} 
Table 1. Top ten countries/territories investing in China (2010) \\
\hline Country/territories & FDI inflows (Millions USD) \\
\hline Hong Kong (China) & 60566.8 \\
Virgin Islands & 10447.3 \\
European Union & 5483.6 \\
Singapore & 5428.2 \\
Japan & 4083.7 \\
United States & 3017.3 \\
Korea & 2692.2 \\
Cayman Islands & 2498.8 \\
Taiwan (China) & 2475.7 \\
Samoan & 1773.3 \\
\hline
\end{tabular}

Source: National Bureau of Statistics (2011).

Provinces in China were categorized into four groups: North Coast areas, Middle Coast areas, South Coast areas and Inland areas according to their geographical location. As can be seen from Table 2, Taiwanese firms ventured 17039 FDI projects in China in the period between 1999 and 2010 and $85.81 \%$ of Taiwanese projects were located in the 
South Coast and Middle Coast areas. This fact indicates the significant agglomeration of Taiwanese FDI in China.

As FDI has a great contribution to economic development, which makes China has witnessed a large disparity in economic growth between coastal and inland areas. Although China's government has decided to extend "open door" policies to the central and western areas after its entrance into the WTO, the agglomeration effect still serves as FDI determinant, thus attracts a large amount of investment in the coastal region. This makes interior regions fall behind in attracting foreign investment and facilitates the uneven distribution of FDI in China. In the period between 1999 and 2003, 89\% of FDI projects were located in the South Coast and the Middle Coast areas while those areas just accounted for $17 \%$ of China's population and $32 \%$ of total GDP (Lien \& Filatotchev, 2015), thus created a vast of untapped market in other regions outside the FDI agglomeration. In recent years, foreign investors including Taiwanese firms have a tendency to expand into the North Coast and the Inland areas, to be specific, the share of FDI projects in the North Coast and Inland areas increased significantly from $11.4 \%$ in 2000 to $29.6 \%$ in 2010 .

Table 2. Distribution of total Taiwanese FDI in China

\begin{tabular}{llllll}
\hline Year & North Coast & Middle Coast & South Coast & Inland area & Total projects \\
\hline 1999 & 21 & 196 & 221 & 50 & 488 \\
2000 & 27 & 424 & 320 & 69 & 840 \\
2001 & 41 & 683 & 352 & 110 & 1186 \\
2002 & 114 & 1378 & 1413 & 211 & 3116 \\
2003 & 171 & 1671 & 1750 & 283 & 3875 \\
2004 & 63 & 734 & 1055 & 152 & 2004 \\
2005 & 60 & 614 & 471 & 152 & 1297 \\
2006 & 52 & 525 & 400 & 113 & 1090 \\
2007 & 65 & 473 & 331 & 127 & 996 \\
2008 & 40 & 300 & 221 & 82 & 643 \\
2009 & 50 & 278 & 168 & 94 & 590 \\
2010 & 68 & 418 & 225 & 203 & 914 \\
Total & 772 & 7694 & 6927 & 1646 & 17039 \\
& $(4.53 \%)$ & $(45.16 \%)$ & $(40.65 \%)$ & $(9.66 \%)$ & \\
\hline
\end{tabular}

Source: Investment Commission (MOEA) (2010).

However, studies on determinants of that encouraging firms to invest outside the FDI agglomeration areas still remain limited, particularly empirical research using firmlevel data. FDI plays an important role in stimulating economic growth, facilitating technology transfer, upgrading managerial and labor skill and creating employment opportunities, therefore, attracting FDI is one of the important missions for the provincial government, especially in less-explored areas where development potential is limited due 
to the lack of foreign investment. This problem is also important to Chinese government who want to attract FDI into less-explored areas through which reduce the huge disparity in economic development between coastal and inland areas. Thus, the lack of knowledge on how less-explored areas attract foreign investment might not allow policy-makers to design appropriate policies in order to utilize their comparative advantages to capitalize the foreign investment. Moreover, multinational enterprise (MNE) without knowledge about comparative advantages of locations outside the agglomeration areas are less likely to enter those locations to explore beneficial investment opportunities. This research is conducted in order to fill the gap of literature about FDI location decision by identifying factors that can attract FDI to locations outside agglomeration areas. Besides, the moderating effect of FDI experience will also be examined because firms may use different criteria when choosing a location depending on their FDI experience.

\section{HYPOTHESIS DEVELOPMENT}

Market potential including market size, living standard, and market growth is one of the most important determinants of FDI location choice both at national and subnational levels, especially for foreign firms with market seeking motive because this factor directly affects the expected revenue from the domestic market. Ang (2008) found that a $1 \%$ increase in market size might increase $0.95 \%$ of inward FDI, which means an almost one-to-one relationship. Researchers on the effect of market characteristics on the decision to venture FDI outside the agglomeration areas, especially at the sub-national level is currently limited. Driffield, Jones, and Crotty (2013); Lien and Filatotchev (2015); and Huang and Wei (2016) analyse the impact of market potential on FDI location decision in less-explored areas using quantitative method and agree that market size, living standard, and market growth have positive relationship with decision to locate FDI in riskier provinces which are unpopular with FDI. This shows that FDI conducted outside the agglomeration areas might derive from market-seeking motive. A large market size which is represented by the high number of the population might reflect a high demand for goods and services and allow economies of scale production.

In addition, the study of Huang and Wei (2016) implies that cities in agglomeration areas are losing their competitive advantage on market size because the high concentration of FDI means that local need has been fully served by a large number of firms, so later FDI has less opportunity to explore that large market. Conversely, the demand in less-explored areas is not fully satisfied due to the lack of FDI here. So, foreign firms are more likely to invest outside to seek for the new potential market. In addition, foreign enterprises investing in less-explored areas will be able to achieve first mover advantage and have greater bargaining power with other stakeholders such as suppliers and customers, thus receive higher potential profit. Beside market size, living standard is another consideration in the FDI location choosing process because higher living standard represents higher spending power and consumption ability that can directly affect local market-oriented strategy even in unpopular areas of FDI. Moreover, most of FDI projects are conducted to achieve long-term objectives, so the growth rate of the domestic market might also have an impact on the location choice as it is a signal for potential profit in the future. The impact of market potential on FDI location choice is reflected in the following hypotheses: 
- H1: Market size has a positive influence on MNE's decision to locate FDI outside the agglomeration areas in China;

- H2: Living standard has a positive influence on MNE's decision to locate FDI outside the agglomeration areas in China;

- H3: Market growth has a positive influence on MNE's decision to locate FDI outside the agglomeration areas in China.

Previous researchers about the impact of labor factors on the decision to locate FDI outside the agglomeration areas usually receive inconsistent results. The cluster of foreign firms can lead to the increase of labor quality in agglomeration areas, so firms have to pay a higher wage for employing skilled labor force. In contrast, areas outside the agglomeration will have lower labor cost and higher labor availability due to the lack of investment there. Therefore, low labor cost and high labor availability are expected to be the competitive advantage of locations outside the FDI agglomeration areas. Labor quality of less-explored locations might not high enough to compete with that of welldeveloped areas, thus labor quality is not considered in this research. Some researchers argue that high unemployment is associated with low labor cost because it represents the fact that this location lack of suitable employees, so un-skilled labor might receive a lower wage (Hogenbirk \& Narula, 2004). However, Braconier, Norback, and Urban (2005) argue that the link between relative resource endowments and relative prices might be distorted, which means wage cost is driven by not only the labor availability but also other forces such as taxes and labor market conditions. Therefore, labor cost and labor availability is assumed to have different effects on location decision and will be considered separately in this research. Danciu and Strat (2014) and Cai, Wang, and Du (2002) indicate that foreign investors are attracted by the presence of high-skilled labor force in agglomeration areas of FDI, conversely, they are attracted by the low-cost labor force in less-developed regions. Huang and Wei (2016) can not find a significant negative relationship between labor cost and firm's decision to invest in less-explored and riskier locations of emerging economies, which is explained that agglomeration areas are able to reduce labor cost though cheap migrant workers from rural areas.

However, Cai, Wang, and Du (2002) argue that migration from rural to urban has not reached the necessary scale to reduce the wage disparity, especially in China where discrimination against migrants still exists and increases labor market segregation. Therefore, the large relative differences in wage cost might lead to more FDI from skilledlabor abundant to unskilled-labor abundant location (Braconier, Norback, \& Urban, 2005). Foreign investors seem to require higher return when they invest in a location considered as higher risk such as outside the FDI agglomerated areas while low labor cost is a key factor in cost reduction and increasing profit, so low wage can compensate the risky investment and attract foreign investors in less-explored locations. Moreover, multinationals might prefer a location which has plenty of labor which is measured by the unemployment rate. The high unemployment rate could be a signal for the availability of labor force and the willingness to work harder for a lower wage, thus it can attract foreign investors with efficiency-seeking motive. The high availability of labor may attract firms 
seeking for unskilled and cheap labor to locations that are outside the FDI agglomeration. The impact of labor cost and labor availability on FDI location decision is reflected in the following hypotheses:

- H4: Labour availability has a positive influence on MNE's decision to locate FDI outside the agglomeration areas in China;

- H5: Labour cost has a negative impact on MNE's decision to locate FDI outside the agglomeration areas in China.

International firms are more likely to invest in the same country because of learning effect, in other words, the accumulated location-specific experience enable foreign investors to have a better understanding about their investment location, which seems to facilitate their future location choice. According to Buckley, Chen, Clegg, and Voss (2016) and Huett, Baum, Schwens, and Kabst (2014), FDI experiences about host country's investment environment can increase the commitment to the host location and facilitate riskier investment decision in the same country such as moving from assetexploitation to asset-exploration strategy or investing in riskier and less-explored areas in host country. The reason for those actions is that the risks associated with investing in an unfamiliar location such as higher information and search cost will decrease with the accumulation of local knowledge and will be less likely to impede subsequently riskier investment in the same country. Chen and Yeh (2012) indicate that foreign investors use different criteria in location choosing process based on their experience about the host market. In the early investment period, multinationals favor the FDI agglomeration areas to enjoy the benefits of agglomeration economies such as knowledge spillover and specialized production. However, the province's importance seems to reduce when the familiarity with China's business environment increases, which encourage them to venture outside the FDI agglomeration areas to seek for new market and opportunity to reduce production cost.

Following those arguments, FDI experience of Taiwanese firms is assumed to have a moderating impact on the relationship between location characteristics and MNE's decision to locate outside the agglomeration areas of FDI. In the case of market-seeking firms, experiences about China's business environment might help foreign investors to overcome risks associated with operating in the unfamiliar provincial market as they know how to adapt to Chinese local market and tailor their products to local specific requirement at a lower cost. Other in-experienced firms might lack such market knowledge, which leads to higher cost in market research to enter unfamiliar markets. Therefore, those firms are more likely to invest in the agglomeration areas to take advantage of knowledge spillover from other firms. Thus, market size, living standard, and market growth might have a stronger effect on the decision to enter the less-explored market when a firm has prior experience about the host nation. Similarly, when efficiency-seeking firms, which are unfamiliar with market rules, enter a less-explored location in China, they might lack access to local information or supply channel which are necessary to acquire resources effectively or reduce the production cost. Conversely, firms with FDI experience are more likely to be attracted by lower labor cost or high labor availability in less-explored locations. 
- H6: Foreign firms with FDI experience about the host market are more likely to invest in FDI unpopular locations that have at least one of the following conditions: Large market size, high living standard, high market growth, low labor cost and high labor availability.

\section{METHODOLOGY}

\subsection{Empirical model}

FDI location decision has been modeled as a choice among several alternatives made by an individual firm, therefore, the empirically econometric model should have these features too. When there is a large number of alternatives, a computational burden will occur if an estimation procedure admits all the choices at the same time (Shukla \& Waddell, 1991). Previous studies have recommended several options to reduce the choice set such as selecting the subset randomly from the target population (Shukla \& Waddell, 1991) or selecting a fixed subset and add one or more alternatives randomly (Hansen, 1987). However, according to $\mathrm{Wu}$ (2000), those methods of selecting research sample could be problematic when the distribution of foreign firms is extremely uneven because the correlation of alternatives might lead to the violation of the assumption about the independence of irrelevant alternatives (IIA), thus the estimation of the model might not be consistent. In this case, a binary logistic regression model can be applied because the two categories, which are FDI in agglomeration areas and outside agglomeration areas, are assumed not to represent aggregated choice. In other words, the location characteristics are represented individually rather than in aggregated ( $\mathrm{Wu}, 2000)$. In this research, the model attempts to relate the probability of investing outside the agglomeration areas to the province's location characteristics. A model which is based on sliced categories seems to be appropriate, thus a binary logit regression has been applied.

In order to analyze how some location characteristics, affect differently to the decision to venture FDI in or outside the agglomeration areas, location attractiveness is assumed to be composed by a group of independent variables and the chance of investing in or outside the FDI agglomeration might be related to specific location characteristics. While the real attractiveness of a location cannot be observed, the actual FDI location choice of each firm and location characteristics can be observed.

Let the vector $\mathrm{z}$ represent the overall attractiveness of a location. $\mathrm{z}$ is decomposed into a linear combination of a group of independent variables $\mathrm{x}_{1}, \mathrm{x}_{2}, \ldots \mathrm{x}_{\mathrm{n}}$ which are observable location features:

$$
\mathrm{z}=\beta_{0}+\beta_{1} \mathrm{x}_{1}+\beta_{2} \mathrm{x}_{2}+\ldots+\beta_{\mathrm{n}} \mathrm{x}_{\mathrm{n}}
$$

$\mathrm{z}$ is defined by contrasting the chance of venture FDI outside agglomeration areas with the chance of investing in agglomeration areas. A logistic transformation is then adopted in order to capture the non-linear relationship. Therefore, $\mathrm{z}$ is defined as a $\log$ odds of the probability of investing outside the FDI agglomeration to the probability of venturing FDI in the agglomeration areas. 


$$
\mathrm{z}=\ln \left(\frac{\mathrm{p}^{\mathrm{a}}}{\mathrm{p}^{\mathrm{b}}}\right)
$$

where $\mathrm{p}^{\mathrm{a}}$ and $\mathrm{p}^{\mathrm{b}}$ are respectively the probability of investing outside the FDI agglomeration areas and the probability of investing FDI in the agglomeration locations.

Since $p^{a}+p^{b}=1$

The $\mathrm{z}$ can be rewritten as:

$$
\mathrm{z}=\ln \left(\frac{\mathrm{p}^{\mathrm{a}}}{1-\mathrm{p}^{\mathrm{b}}}\right)
$$

The probability of venturing FDI outside the agglomeration areas is known to take the following form:

$$
\mathrm{p}^{\mathrm{a}}=\frac{\exp (\mathrm{z})}{1+\exp (\mathrm{z})}
$$

Or it can be written that:

$$
p^{a}=\frac{\exp \left(\beta_{0}+\beta_{1} x_{1}+\beta_{2} x_{2}+\ldots+\beta_{n} x_{n}\right)}{1+\exp \left(\beta_{0}+\beta_{1} x_{1}+\beta_{2} x_{2}+\ldots+\beta_{n} x_{n}\right)}
$$

Another focus of this research is on how FDI experience about the host market can influence the impact of location characteristics on the decision to invest outside the FDI agglomeration. In ordinary least square (OLS) regression, this hypothesis is usually tested by adding interaction terms in the model, however, this approach seems not to appropriate in non-linear models like the binary logit model. The coefficient of the interaction term in the logit model cannot be considered because its marginal effect as the value of marginal effect depends on the values of all explanatory variables (Ai \& Norton, 2003). Hoetker (2007) suggests that this problem can be solved by splitting the sample based on interaction term and then comparing the estimated coefficients in the subsample of theoretical interest. Therefore, the sample in this research has been split on the basis of firm's FDI experience about China market. This approach allows explanatory variables to have different impacts on the FDI location decision in different sub-groups (Shaver, 1998). If there is at least one location characteristic that has a stronger effect on the decision to invest outside the agglomeration areas when MNEs have prior experience about the host market, the hypothesis about the moderating impact of FDI experience will be supported.

\subsection{Variables}

Dependent variable (OUT) is a dummy variable which indicates whether a specific Taiwanese FDI project is located outside the agglomeration areas of FDI. This 
variable receives the value of 0 if a Taiwanese FDI project is located on the South Coast and the Middle Coast areas including Zhejiang, Jiangsu, Shanghai, Guangdong and Fujian provinces. Conversely, the dependent variable is equal to 1 when Taiwanese investors venture FDI outside the agglomeration areas of FDI. The categories of North Coast and Inland areas in our sample include Guangxi, Shandong, Sichuan, Hubei, Beijing, Hunan, Henan and Jiangxi provinces. The logit model requires that all alternatives must be selected at least once, however, some other provinces in the North Coast and Inland areas such as Tianjin, Liaoning, Chongqing, Hebei, Yunnan or Heilongjiang provinces are quite unpopular with Taiwanese investors. Therefore, those provinces have been removed from the choice set as they receive no Taiwanese investment in our sample. The reduction in the choice set might not affect the empirical estimation because the logit model is built upon the IIA assumption. Detailed definitions of all of the explanatory variables and their expected effects on centrifugal FDI decision are listed in Table 3.

Table 3. Variables, abbreviation, definition and expected impact

\begin{tabular}{llll}
\hline Variable name & Abbreviation & Definition & Expected impact \\
\hline Market size & SIZE & $\begin{array}{l}\text { Population of the province where FDI } \\
\text { project is located in the year investment } \\
\text { begins (million persons) } \\
\text { Living standard }\end{array}$ LIV & $\begin{array}{l}\text { Per capita annual income of the province } \\
\text { where FDI project is located in the year } \\
\text { investment begins (1000 Yuan) } \\
\text { GDP growth rate of the province where FDI } \\
\text { Market growth } \\
\text { project is located in the year investment } \\
\text { begins (\%) }\end{array}$ \\
Labor cost & WAGE & $\begin{array}{l}\text { Average wage per capita of the province } \\
\text { where FDI project is located in the year } \\
\text { investment begins (1000Yuan) }\end{array}$ \\
Labor availability & UNEM & $\begin{array}{l}\text { Number of Unemployment in the province } \\
\text { where FDI project is located in the year } \\
\text { investment begins (10000 persons) }\end{array}$ & + \\
& &
\end{tabular}

\subsection{Data}

Data about Taiwanese FDI in China was collected from the website of Taiwan Stock Exchange Corporation (TSEC). Taiwan's law requires all listed companies to submit their annual report and investment information which have been approved by public accountants on this website, thus it can be considered as a reliable and comprehensive source of data. Firstly, the list of all firms that were traded publicly on the Taiwan Stock Exchange during the period between 1999 and 2010 was gathered from TSEC website. From this sample, 100 companies were selected randomly from 9 groups of industries including food; plastics; textiles; electric machinery; chemical, biotechnology and medical care; trading and consumer goods; electronic part; communication and internet and optoelectronics. There are no regulations from the Chinese government which require those companies to invest in specific provinces, so 
those Taiwanese firms freely choose their investment location. Then we accessed the 2010 annual report of each listed firms and took note the name of each company, its subsidiaries in China, the year when investment began and the location of each subsidiary. 67 firms that have at least one FDI project in China and 33 other firms have been eliminated from the sample because they have no investment in China.

Therefore, the final sample includes 131 FDI projects that were undertaken by 67 Taiwanese listed firms who invested in 12 provinces of China during the study period between 1999 and 2010. There are 12 FDI projects that are considered as investment outside the agglomeration of FDI in the sample. As table 1 shows, $85.81 \%$ of Taiwanese FDI projects are located on the South Coast and Middle Coast areas $(90.84 \%$ in the sample). Thus the distribution of FDI projects in our sample is consistent with the location choice of all Taiwanese FDI firms in China. The sample was then split into two categories: Experienced and non-experienced firms based on whether a Taiwanese firm has made any prior investment in China in order to check the difference in investment behavior between two groups. Overall, there are 72 projects made by experienced firms and 59 projects made by non-experienced firms. The logit model was run separately for each group to check how FDI experience can influence the effect of location factors on location choice. Data about province's characteristics including population, income per capita, GDP growth rate, average wage per capita and the number of unemployment in each China's province was obtained from the National Bureau of Statistics (2011).

\section{EMPIRICAL RESULTS}

Table 4 reports the summary statistics and correlation matrix of variables. There are 131 observations that were collected for each variable. As shown in Table 4, 9\% of FDI projects from Taiwan are located in less-explored areas or outside the agglomeration areas of FDI. The average size of China's provincial market is 69.75 million persons with approximately $12.44 \%$ growth rate. Taiwanese firms have to pay an average wage of 25990 Yuan and there are nearly 35600 persons that are available to be hired.

Table 4. Descriptive statistics and correlation matrix

\begin{tabular}{llllllll}
\hline & Mean & $\begin{array}{l}\text { Standard } \\
\text { Deviation }\end{array}$ & SIZE & DEM & GROW & WAGE & UNEM \\
\hline OUT & 0.09 & 0.278 & & & & & \\
SIZE & 69.75 & 24.49 & 1 & & & & \\
LIV & 15.68 & 6.53 & $-0.19^{*}$ & 1 & & & \\
GROW & 12.44 & 1.87 & $0.28^{* *}$ & 0.13 & 1 & & \\
WAGE & 25.99 & 9.74 & $-0.50^{* *}$ & $0.73^{* *}$ & $-0.35^{* *}$ & 1 & \\
UNEM & 35.60 & 8.99 & $0.39^{* *}$ & $-0.36^{* *}$ & 0.02 & $-0.26^{* *}$ & 1 \\
\hline
\end{tabular}

The effect of variables related to market potential and labor market on FDI location choice has been tested by running the model separately for each group. Model 1 includes only variables that represent the market potential of a particular location which are market size (SIZE), living standard (LIV) and market growth (GROW). Model 2 
indicates the effect of factors related to the labor market, such as labor cost (WAGE) and labor availability (UNEM), on the location decision of Taiwanese firms in China. All explanatory variables which are SIZE, LIV, GRO, WAGE, and UNEM are included in Model 3 in order to test their effect on the location choice of Taiwanese firms. The results presented in Table 5 reveal that market size and labor cost variables are both related to MNEs' decision to invest outside the agglomeration areas in China. In terms of market size variable, its coefficient is 0.015 and significant at $10 \%$. The coefficient of SIZE is 0.015 , which is the log odds of two categories of site or the ratio of the probability of choosing to locate FDI outside the agglomeration areas to the probability of venturing inside the FDI agglomeration areas. The log odds can be transformed into odds to examine the meaning of the coefficient more easily. In this case, $\exp (0.015)=1.015$, which means that with every increase of 1 million persons, the odds of investing outside the agglomeration areas to investing in agglomeration areas increase by $1.5 \%$. This corroborates the hypothesis that market size factor is positively related to firm's decision to invest outside the FDI agglomeration areas.

Table 5. Estimation results for Binary logit models

\begin{tabular}{llllll}
\hline & Model (1) & Model (2) & Model (3) & Model (4) & Model (5) \\
\hline SIZE & $0.015^{* *}$ & & $0.015^{*}$ & $0.137^{*}$ & 0.080 \\
LIV & 0.084 & & 0.224 & 0.157 & 3.227 \\
GROW & $0.999^{*}$ & & 0.195 & 0.168 & -0.243 \\
WAGE & & $-0.592^{* * * *}$ & $-0.291^{*}$ & $-0.251^{*}$ & -2.016 \\
UNEM & & -0.041 & 0.035 & 0.032 & -0.424 \\
Constant & $-31.063^{* * *}$ & $11.293^{* * *}$ & -16.445 & -14.378 & -10.447 \\
\hline Number of observation & 131 & 131 & 131 & 72 & 59 \\
Log likelihood & 22.682 & 43.002 & 19.441 & 18.059 & 19.472 \\
Chi-squared test & $52.868^{* * *}$ & $32.548 * * *$ & $56.109 * * *$ & $32.172^{* * * *}$ & $23.718^{* * *}$ \\
\hline
\end{tabular}

Conversely, the coefficient of WAGE variable is -0.291 and is significant at $10 \%$, which means every increase of 1000 Yuan in labor wage might decrease the odds of investing outside the agglomeration areas to investing in agglomeration areas by $25.2 \%$, thus H5 is supported. Market growth variable is not always significant across the logistic models, therefore, it might be hard to explain its positive sign, which means that the increase in market growth rate does not increase the probability of less-explored provinces to be chosen as FDI location, so the hypothesis $\mathrm{H} 3$ is rejected. The other two variables, LIV and UNEM, do not show a significant relationship with the location choice of Taiwanese investors, thus, $\mathrm{H} 2$ and $\mathrm{H} 4$ are also rejected. Model 4 shows the results for investors having prior experience about China market, in other words, this model shows the result for those who have at least one investment in China before the considered FDI project. The results show that the estimated coefficient of market size is positive while the negative sign of labor cost is recognized and both variables are significant at $10 \%$. The magnitudes of the two effects suggest that the effect of labor cost on location choice is larger than that of market size in the subgroup of experienced Taiwanese firms. There 
is no significant and reliable relationship between location choice of experienced investors and other variables such as living standard, market growth, and labor availability. It is interesting to note that when investors have no prior experience about China market, the effects of location factors on location choice are different (Model 5). In our sample, none of the location characteristics variables are significant in this subsample. Thus, market size and labor cost only have an impact on the decision to locate FDI outside the agglomeration areas when Taiwanese firms have prior experience about the host market, so hypothesis H6 that FDI experience has a moderating effect on location choice is supported.

\section{DISCUSSION}

Researchers on China's FDI have identified cheap labor cost and large market size as important determinants for multinationals to invest among China's provinces (Dees, 1998). Before China' entrance to the World Trade Organization (WTO) in 2001, most of FDI was concentrated in the South Coast and Middle Coast of China not only because of the comparative advantage in transportation and communication convenience, large market size and cheap labour cost but also because of open door policies and incentives for foreign investments in coastal areas such as reduction and exemptions on taxes and land use fees, relaxation of labour management rules or providing superior infrastructure facilities. However, the development zones with preferential policies for foreign investors seem to lose the advantage in preferential policies as a result of China's accession to the WTO (Huang \& Wei, 2016) because Chinese government also applied "open door" policies and attractive incentives for foreign investment to other provinces in China. In addition, according to Chan, Henderson, and Tsui (2008), when the FDI concentration in a province reaches a high level, this location will suffer from several agglomeration diseconomies and gradually lose their comparative advantages because of negative externalities, for instance, increasing labor cost, transportation bottleneck or population. Thus, comparative advantages like lower-cost labor or large market, which used to be main determinants of FDI into the South Coast and Middle Coast areas in China, might shift to other locations outside the FDI agglomerated areas like the North Coast and Inland areas. This does not imply that the South Coast and Middle-Cost areas are losing their competitiveness in attracting Taiwanese investments, the fact is that the agglomeration economies and its positive effects are currently playing an important role in attracting FDI to those core locations. Therefore, the FDI agglomeration areas will attract investors who are looking for high labor quality or knowledge spillover effect while other firms with market-seeking and efficiency-seeking motives might decide to enter less-explored areas outside the agglomeration to access large markets and cheap labor. This assessment is supported by our empirical results which indicate that the market size and labor cost respectively positively and negatively affect the firm's decision to enter locations outside the agglomeration areas.

Our findings of the positive relationship between market size and the decision of Taiwanese investors to venture FDI outside the agglomeration areas in China substantiated much of the previous knowledge which identified the role of market size in attracting FDI into a specific location. Ang (2008) found an almost one-to-one relationship between the size of the domestic market and FDI inflows and it was explained 
by the benefits of the economics of scale. We also found a positive relationship but the effect of market size on FDI location choice is weaker. This could be explained that this research analysed FDI in the context of investment outside the agglomeration areas of FDI, so the effect of location characteristics on FDI location choice of foreign investors might be deterred by the higher risk associated with investment in less-explored locations such as institutional uncertainty or transactional risks of dealing the unfamiliar local partners (Lien \& Filatotchev, 2015). Other researchers about FDI location decision in 'zero-FDI states', conflicting locations or last desirable regions have previously suggested a positive effect of market size on location choice (Driffield, Jones \& Crotty, 2013; Alecsandru \& Raluca, 2015). Firms with a market-seeking motive would enter a location which had a large market size even if it was considered as a less-explored and riskier area because by responding to market demand, firms could still generate profit and achieve economies of scale production within a region that had a high number of population. In the case of China, nearly $90 \%$ of FDI projects were concentrated in the South Coast and Middle Coast areas, however, these areas just accounted for $17 \%$ of China population in 2003 (Lien \& Filatotchev, 2015), which indicates a large untapped market for foreign investments in other regions of China because the demand was not fully satisfied in those markets due to the lack of FDI. Moreover, foreign firms could not only avoid the high pressure of competition in the FDI agglomeration areas but also be able to achieve first-mover advantage and gain greater bargaining power with domestic stakeholders when they entered untapped markets that had fewer competitors like lessexplored locations.

Researches about the relationship between labor cost and firm's decision to enter less-explored market usually show a wide variety of results. Huang and Wei (2016) can not find a statistically significant relationship between labor cost and location choice in a less-explored location in emerging economies, which is explained by the fact that firms operating in the agglomeration areas of FDI can reduce labor cost through hiring cheap migrant workers from other regions in China. However, our results support the opposite argument of Cai, Wang and Du (2002) that the migration of workers from interior China or from rural regions of China has not reached a scale necessary to eliminate the difference in labor cost between developed and less-developed regions in China. In addition, the concentration of FDI in agglomerated areas might increase the wage disparity across regions, to be specific, the average wage in the South Coast and Middle Coast in China, including labour cost for both skilled and unskilled workers, is on average $25 \%$ higher than the average wage in the North Coast and Inland areas. Moreover, the FDI agglomerated areas have comparative advantages in technology, management skill, capital, and infrastructure; conversely, other less-explored areas have an abundance of relatively low skilled labor force (Liu, Daly, \& Varua, 2014). Thus, foreign firms that operate in labor-intensive industries or low-tech manufacturing production might have the tendency to move outside the agglomerated location to look for the cheaper labor force, which can explain why the decision to locate FDI in less-explored areas reacts negatively to the labor cost.

The result indicates that experienced firms are more likely to enter less-explored areas when the market size in those areas increases or labor cost decreases, however, we 
can not find any significant relationship between location characteristics and nonexperienced firms' decision to invest outside the FDI agglomeration areas. This is consistent with the results of Chen and Yeh (2012) and Huett et al. (2014) who indicate that foreign investors might adjust their criteria for choosing FDI locations based on their accumulated FDI experience about the host nation's market, especially for marketseeking and efficiency-seeking enterprises as these experiences increase their commitment to the host nation, reduce the cost associated with less-explored location such as information searching cost. Thus, they can better serve the local market and better access to local resources like the low-cost labor force, which enables them to create value from comparative advantages even in provinces outside the agglomeration areas. Conversely, foreign investors without local market experience might follow the investment location of other firms and less likely to take the higher risks and higher costs associated with resource exploration in unpopular locations as those costs may deter the ability to create value from comparative advantage of less-explored locations. Therefore, FDI experience has a moderating effect on the relationship between location characteristics and FDI location choice, in other words, market-seeking and efficiencyseeking enterprises with FDI experience about host markets are more likely to invest outside the agglomeration areas to access large market size and low labor cost.

\section{CONCLUSION}

The finding of this research is that location characteristics only partially explain the location choice as multinationals consider both location factors and firm's specific resource such as FDI experience when venturing FDI outside the agglomeration areas. In other words, firms choose a specific location because they are motivated by the comparative advantage of this location and have necessary resource to do so. In the case of Taiwanese firms, their prior experience about China's market might encourage them to invest outside the agglomeration areas in order to take advantage of the large market size and low-cost labor force in those areas.

This research has contributed to the FDI location decision literature in several ways. First, most of the previous research about FDI location choice and the agglomeration of FDI mainly examines the factors that can lead to the cluster of firms in some specific location in the host country or the effect of agglomeration on later FDI location decision. The main contribution of this research is to explore factors which can encourage firms to locate outside the FDI agglomeration areas, thus bridging the gap of FDI agglomeration literature. Second, this study contributes to the literature about FDI location choice by exploring that location characteristics only partially explain the FDI location choice as foreign firms consider both locational factors and firm's specific resources such as FDI experience when entering a location outside the agglomeration areas or it can be said that firms venture FDI in a specific area because they are motivated by comparative advantages of that location and have resource and skill necessary to do so. Third, the result indicates that location characteristics have an impact on firms' decision to invest outside the FDI agglomeration only for specific subsample, which might explain why previous studies report inconclusive results regard to the relationship between location factors and firms' decision to enter less-explored locations (Demekas, Horvath, Ribakova, \& Wu, 2007; Huang \& Wei, 2016). 
For MNEs' managers, the implication of this research is twofold. First, foreign firms should be more proactive to explore the untapped international market outside the agglomeration areas because less-explored locations also have comparative advantages which allow firms to achieve their investment objective and remain competitive. For instance, this research has indicated that the North Coast and Inland areas in China with large market size and low labor cost are appropriate for market-seeking and efficiencyseeking MNEs. Second, although firms have to accept the increased risks associated with investment on less-explored areas (Lien \& Filatotchev, 2015), managers can mitigate those risks by determining firm's comparative advantage when investing outside the agglomeration in the host nation. For example, foreign firms that have prior experience about the host market might be better in realizing location advantage and effectively exploring profitable investment opportunities such as vast and untapped markets outside the agglomeration or cheaper production sites.

Several policy implications are identified for policy-makers who want to capitalize FDI into less-explored areas in order to reduce the uneven distribution of FDI and the development disparities among provinces. The host authority should understand the comparative advantage which can attract FDI into their home, then they will be able to offer suitable intensives for foreign investors. Based on the result of this research, Taiwanese firms with previous experience about the host market are more likely to invest outside the FDI agglomeration where there are large market size and low labor cost, so the incentive policy should focus more on experienced firms and provide them opportunities to achieve market-seeking and efficiency-seeking motives. Moreover, the strategy of multinationals toward a specific location might change over time, for example, the agglomeration areas in China have lost their advantage in large market size and low labor cost and currently attract foreign investment by its agglomeration economies. Therefore, policy-makers need to check their location advantages regularly and offer appropriate policies.

This research has limitations as discussed in the following. First, the data collected did not cover all the target population and it was gathered over a limited period of time, which may cause some biases. The sample size is quite small, suggesting that different results might be obtained if a larger sample or different time periods are utilized. Second, this research is limited to FDI location choice of Taiwanese firms. The focus on Taiwanese FDI has several advantages for studying such as the availability of FDI data or the mitigation of cultural effect on investment behavior. However, this limits our perspective to enterprises from other nations. Third, the coding of location choice as dichotomous variable separating between investment in and outside the FDI agglomeration might lead to a certain degree of simplification because both groups include a heterogeneous subgroup of provinces with different advantages and development levels.

Further studies could take account for the difference between provinces within each group, for example, the group of provinces located outside FDI agglomeration can be split based on the criterion whether that province is located next to the agglomeration areas or not. Head, Ries, and Swenson (1995) argue that the geographic extent of 
manufacturing agglomeration does not end at the state border, which means the attractiveness of state increase with the level of industrial activity in the neighboring state. Therefore, the externalities of agglomeration effect cross-province boundaries might increase the attractiveness of provinces located next to FDI agglomerated provinces compared to other provinces located far away. Moreover, it could also be interesting to investigate what attract firms from other countries to locate outside the FDI agglomeration in China, which will allow researchers to explore the effect of cultural factors on the investment behavior.

\section{REFERENCES}

Ai, C., \& Norton, E. C. (2003). Interaction terms in logit and profit models. Economics Letters, 80, 123-129.

Alecsandru, S. V., \& Raluca, D. A. (2015). A regional level hierarchy of the main foreign direct investments' determinants. Procedia - Social and Behavioural Sciences, $181,321-330$.

Ang, J. B. (2008). Determinants of foreign direct investment in Malaysia. Journal of Policy Modelling, 30, 185-189.

Baum, J. C., \& Mezias, S. (1992). Localized competition and organizational failure in the Manhattan hotel industry, 1989-1990'. Administrative Science Quarterly, 37(4), 580-604.

Braconier, H., Norback, P., \& Urban, D. (2005). Multinational enterprises and wage costs: Vertical FDI revisited. Journal of International Economics, 67, 446-470.

Buckley, P. J., Chen, L., Clegg, L. J., \& Voss, H. (2016). Experience and FDI risk-taking: A micro foundational reconceptualization. Journal of International Management, $22,131-146$.

Cai, F., Wang, D., \& Du, Y. (2002). Regional disparity and economic growth in China: The impact of labor market distortions. China Economic Review, 13, 197-212.

Chan, K. W., Henderson, J. V., \& Tsui, K. Y. (2008). Spatial dimensions of Chinese economic development. Applied Geography, 43, 776-828.

Chen, C., \& Yeh, C. (2012). Re-examining location antecedents and pace of foreign direct investment: Evidence from Taiwanese investments in China. Journal of Business Research, 65, 1171-1178.

Cheng, K., Chiao, Y., Shih, H., Lee, T., \& Cho, T. (2011). Agglomeration and competition among Chinese cities: An investigation of Taiwanese high-tech foreign direct investment. Growth and Change, 42(4), 517-548.

Danciu, A. R., \& Strat, V. A. (2014). Factors influencing the choice of foreign direct investments locations in the Romanian regions. Procedia - Social and Behavioral Sciences, 109, 870-874.

Dees, S. (1998). Foreign direct investment in China: Determinants and effects. Economics of Planning, 31, 175-194. 
Demekas, D. G., Horvath, B., Ribakova, E., \& Wu, Y. (2007). Foreign direct investment in European transition economies - The role of policies. Journal of Comparative Economics, 35, 369-386.

Driffield, N., Jones, C., \& Crotty, J. (2013). International business research and risky investment, an analysis of FDI in conflict zones. International Business Review, $22,140-155$.

Filatotchev, I., Strange, R., Piesse, J., \& Lien, Y. C. (2007). FDI by firms from newly industrialised economies in emerging markets: Corporate governance, entry mode and location. Journal of International Business Studies, 38, 556-572.

Hansen, E. (1987). Industrial location choice in Sao Paulo, Brazil. Regional Science and Urban Economics, 17, 89-108.

Head, K., Ries, J., \& Swenson, D. (1995). Agglomeration benefits and location choice: Evidence from Japanese manufacturing investments in the United States. International Journal Economics, 38, 223-247.

Hoetker, G. (2007). The use of logit and profit models. Strategic Management Journal, 28, 331-343.

Hogenbirk, A., \& Narula, R. (2004). Location and agglomeration of FDI in the Netherlands: Implications for policy. Growth and Change, 39(3), 389-413.

Huang, H., \& Wei, Y. D. (2016). Spatial inequality of foreign direct investment in China: Institutional change, agglomeration economies, and market access. Applied Geography, 69, 99-111.

Huett, P., Baum, M., Schwens, C., \& Kabst, R. (2014). Foreign direct investment location choice of small- and medium-sized enterprises: The risk of value erosion of firmspecific resources. International Business Review, 23, 952-965.

Investment Commission (MOEA). (2010). Taiwan FDI statistics summary analysis 19992010. Retrieved from https://www.moeaic.gov.tw.

Kang, Y., \& Jiang, F. (2012). FDI location choice of Chinese multinationals in East and Southeast Asia: Traditional economic factors and institutional perspective. Journal of World Business, 47, 45-53.

Li, S., \& Park, S. H. (2006). Determinants of locations of foreign direct investment in China. Management and Organization Review, 2(1), 95-119.

Lien, Y., \& Filatotchev, I. (2015). Ownership characteristics as determinants of FDI location decisions in emerging economies. Journal of World Business, 50, 637650.

Liu, K., Daly, K., \& Varua, M. E. (2014). Analysing China's foreign direct investment in manufacturing from a high-low technology perspective. Emerging Markets Review, 21, 82-95.

National Bureau of Statistics (NBS). (2011). China statistics yearbooks 1999-2011. Beijing, China: Statistical Publishing House. 
Shaver, J. M. (1998). Accounting for endogeneity when assessing strategy performance: Does entry mode choice affect FDI survival? Management Science Journal, 44(4), 571-585.

Shukla, V., \& Waddell, P. (1991). Firm location and land use in discrete urban space: A study of the special structure of Dallas-Fort Worth. Regional Science and Urban Economics, 1, 225-253.

$\mathrm{Wu}, \mathrm{F}$. (2000). Modelling intra metropolitan location of foreign investment firms in a Chinese city. Urban Studies, 37(13), 2441-2464. 